\title{
OCCUPATIONAL AND ANIMALS SAFETY IN ZOOS: A LEGAL NARRATIVE
}

\author{
Kamal Halili Hassan \\ Faculty of Law, University Kebangsaan Malaysia, Bangi, 43600, Selangor, Malaysia
}

Received 2013-08-15; Revised 2013-09-19; Accepted 2013-12-27

\begin{abstract}
This article examines the legal position of human and animal safety in zoos. The risk of injury or even death is high in zoos. Such risk can occur either to the people in charge of zoos, visitors or even to the animals themselves. As such, there are regulations enacted to safeguard people and animals from such risk. Tort is the primary law that governs liability of owner or management of a premise such as a zoo. Negligence and occupier's liability is the main branch of tort law which is the most relevant to accidents in zoos. Preventive law such as the Occupational Safety and Health Act and the Factories and Machinery Act are also used in ensuring safety at the work place (zoos). For the welfare and safety of animals captivated in zoos, the Wildlife Conservation legislation is enacted to ensure that animals or wildlife are treated well. Such is the scope of the article. The hypothesis of the study is that an effective law will ensure safety to human employed in and people visiting zoos and animals captivated in the zoos. The management of zoo differs from the management of other organizations. The methodology adopted is legal narrative and analysis with reference to legal instrument such as statutes passed by Parliament (legislative body). This article uses Malaysian law as a point of reference. The study finds that Malaysian law governing safety management in zoos is still inadequate.
\end{abstract}

Keywords: Zoos, Animals, Wildlife, Regulations, Accident, Malaysian Law

\section{INTRODUCTION}

The risk of injury or even death is high in zoos. Such risk can occur either to the people in charge of zoos, visitors or even to the animals themselves. It is because of that there must be clear regulations enacted to govern or manage national or local zoos. Safety issues at animal zoos can be viewed from two perspectives: (i) the occupational safety and health of human and (ii) the inhabitants (animals) of the zoos. The former refers to the safety of employees at work, non-employees who include contractors, sub-contractors and their workers, visitors and licensees. The latter refers to the animals kept or captivated in the zoos. Whereas legal protection has been adequately enacted for the people, there are not many regulations enacted for the animals. This article will explore issues of law on safety at zoos covering both people and animals. For such purpose, I will use Malaysian law as a point of reference.

Zoo management has its own uniqueness (Conway, 1995; Forthman and Ogden, 1992; Manning, 2013). Bad management of the zoo can result in accidents. Accidents at zoo happened in many countries. For example, there have been two tiger attacks at the San Francisco Zoo, both involving a 4 year old Siberian Tiger named Tatiana (June $27,2003)$. In this incident, a zookeeper was bitten on the arm during a public feeding. During the second incident two people were injured and one killed, before the tiger was fatally shot by police officers (Fagan et al., 2007). A lion captivated at Johannesburg zoo had killed an employee who had worked there for 40 years (Laing, 2013).

On December 25, 2007, an animal named Tatiana escaped from her open-air enclosure at the San Francisco Zoo and attacked three visitors shortly after closing time (Derbeken and Fagan, 2007). In another incident, a worker in Johannesburg South African zoo was killed by an animal kept in the zoo. Also, an African elephant captivated in a zoo in New Zealand killed a worker (Podell, 2008). Recently, Helen Schofield, a New Zealand zookeeper was killed by Milla, the elephant (Manning, 2013). 
Theoretically speaking, an accident or mishap is an unforeseen and unplanned event or circumstance, often with lack of intention or necessity. It usually implies an outcome which may have been avoided had circumstances leading up to the accident been recognized and acted upon, prior to its occurrence. A hazard has a slightly different meaning; it refers to a potential source of harm or adverse health effect on a person or persons.

The terms hazard and risk are often used interchangeably. Hazard usually refers to the state of things that can give rise to a risk. Risk is the likelihood that a person may be harmed or suffers adverse health effects if exposed to a hazard. Theories on causation of accident have been widely discussed but for this study suffice to note that among the famous theories is Domino theory. Popularized by Heinrich (1959), this theory concludes that: (i) $88 \%$ of occupational accidents are caused by unsafe acts of fellow employees; (ii) $10 \%$ of occupational accidents are caused by unsafe conditions; (iii) $2 \%$ of occupational accidents are unavoidable. The cause of accidents could also due to several causes, hence the multi-causes theory (Bahari, 2002). It could be the result of human error, negligence, defects of places and premises or unguarded machines or exposes to dangerous substances.

\section{MATERIALS AND METHODS}

The prevention of occupational accidents can be divided into civil and criminal liabilities. Civil liability is an outcome of civil claim made by a party suing another party in an individual suit. For accident cases, civil claim is well-known in the context of the law of torts. The law of tort can be applied in the case of accidents in zoos, either under negligence or occupiers' liability claim. Tort law is a non-written law which basically not governed by legislation. The purpose of civil claim is to obtain damages or compensation. The aim of criminal liabilities on the other hand is to punish offenders. Deterrence has being the primary philosophy behind criminal punishment. For prevention of accident cases in zoos, the criminal legislations (legal materials) which can be used are Occupational Safety Health Act 1994 and Factories and Machinery 1967. These are the materials used, beside tort law, for this study. The Protection of Wildlife Act 2010 and its regulations are also referred to in this article in discussing wildlife/animals welfare and safety kept in zoos and national parks.

The research methodology is primarily qualitative. In legal research, data collection relies on primary and secondary data. Primary data refers to legislation, parliamentary hansards and court cases from local and foreign countries. Secondary source refers to publication such as articles' journals, books, thesis and official documents. The approach adopted will be a comparative analysis-adopting and modifying document from foreign jurisdictions; and critical analysis of the law itself. For this study, I have used a tabling method where legal duty and provisions are compartmentalised and explained.

\section{RESULTS AND DISCUSSION}

An owner or controller of a zoo can be sued under the law of tort. Under tort law, the employer or occupier has the duty of care not to cause injury to his employees or any other person (Rogers et al., 2010; Turner and Hodge, 2004). There are several elements that a plaintiff (a person who sues) needs to prove in order to succeed in his claim (Talib, 2010; Turner and Hodge, 2004). A defendant (a person who is being sued) may also offer a defence (s) to nullify the plaintiff's claim. Table 1 presents the legal duty of a party in proving or defending a claim for negligence. A plaintiff has to prove, firstly, that the defendant owes a duty of care to him, who is considered as 'neighbour' under negligence law (Clerk and Jones, 2012; McMahon and Binchy, 2000; Turner and Hodge, 2004). The degree of proof is $100 \%$; he must prove it that the defendant has that duty.

The 'neighbour' principle is derived from a famous case of Donough v. Stevenson (1932) AC 562. Briefly, the plaintiff suffered from nervous shock after drinking ginger beer from an opaque bottle which contained a snail. There was no contract between the consumer and the manufacturer in that case but the 'neighbour principle' allowed the consumer to sue the manufacturer. The consumer has a duty of care towards all its consumers who he can foresee that his actions will likely cause damage to his 'neighbours', if he breaches that duty of care. Against this legal principle, a zoo owner or operator has a duty to take care towards its employees, licensees and visitors.

Secondly, the plaintiff has to prove that the defendant has breached the duty of care (Jones, 2003; McMahon and Binchy, 2000). Such breach of duty of care must result in direct damage to the defendant. For direct damage, a more than $51 \%$ proof of breach must be established. The burden to prove is on the balance of probabilities. However, the damage must be not too remote and there should also be no supervening factor or event that breaks the chain of causation between duty of care and breach of such duty (Murphy and Witting, 2012). Causation in negligence claim needs to be established; the plaintiff must establish that the loss they have suffered was directly caused by the defendant. Causation may be problematic where there exists more than one possible cause. 
Table 1. Tort claim (Negligence)

\begin{tabular}{lll}
\hline Party & To prove & $(\%)$ \\
\hline Plaintiff & Duty of care & 100 \\
Plaintiff & Breach of duty of care & $51-100$ \\
Plaintiff & Damage & $51-100$ \\
Defendant & Consent & $51-100$ \\
Defendant & Knowledge & $51-100$ \\
Defendant & Cost and practicality & $51-100$ \\
\hline
\end{tabular}

The remedy under tort law is in a form of compensation given to the successful plaintiff in his suit, in the form of apology and money (Cooke and John, 2007; McMahon and Binchy, 2000; Turner and Hodge, 2004). The amount of damages granted by court varies from $51 \%$ to $100 \%$ dependent on the degree of liability incurred.If there is contributory negligence by the plaintiff, the amount of damages is divided accordingly. In accidents at zoos, the injured person might have contributed to the injury suffered.

The defendant may also offer his defences against the plaintiff's claim. For example, the defendant may argue that the plaintiff has consented to the incidence. It is difficult to quantify consent given by the plaintiff. A visitor, for example, could not be said to give his consent to get injured although he consented to enter into the premises. However, the consent could be argued around 60 to $100 \%$ that the visitor or staff has given his consent to be subject to injury. Knowledge is also another defence available to the defendant. If the plaintiff has knowledge about the possible danger that could occur and still take the risk, that will minimize the fault committed by the plaintiff. Cost is also a consideration available for the defendant's defence. If it can be proven that the cost to eliminate or minimize the danger is too exorbitant whereas the risk is small, then that defence of cost can be successfully used by the defendant. However, in cases of risk that could endanger life, cost plays a minimum role.

Occupiers' liability is an expansion of negligence law. An occupier such as the owner or controller of the zoo can be held liable for any accidents that occurred in the zoo. An occupier is liable when the state of things at his premises is such that could endanger his visitors. It deals with liability that may arise from accidents caused by the defective or dangerous condition of the premises.

Table 2 presents salient provisions of duties in industrial safety as provided by the Occupational Safety and Health Act 1994 (Kamal, 1994; 2011). However a crucial question needs to be asked: Does the Act apply to zoo services? If it is not, then the Act is not applicable to zoos. The answer would depend on whether 'zoo services' is listed under the 1st Schedule of the Act? No specific reference to zoos is made in the Schedule. Can we argue then that zoos' services fall under 'business services'? ('Business services' is the closest category of industry mentioned in the Schedule that can arguably cover zoos). Business services refer to activities which is mainly profit oriented. A question arises whether zoos are monetary profit oriented? In Malaysia, zoos are not of that orientation although visitors are charged for entry into the zoos. If that is the case then zoos is arguably not covered by the Act. However, if the meaning of 'business services' is expanded to include zoos' businesses, then the OSHA governs zoos and all the provisions therein have to be applied by zoo operators.

Further question that arises is whether zoos services fall under the Factories and Machinery Act 1967? The application of any industry under FMA depends on whether its activities falls under the term 'factory' as defined under the Act (s.2) (Hassan, 2001). It looks that zoos activities do not fall under the activities or nature of work as defined under s. 2. Furthermore the work 'must be carried out by way of trade for the purposes of gain or incidentally to any business so carried', which zoos activities arguably do not satisfy such definition. However the amendment of the Act in 2006 has included 'amusement park' under the coverage of the Act. 'Amusement park' is defined as a tract or area used principally as a location for amusement devices and structures. Arguably, if there are amusement devices and structures installed in zoos, then the FMA can be applied.

Table 3 provides several duties that the employer/occupier of a place need to undertake in ensuring safety at their workplace. Because the two Acts (FMA and OSHA) are concurrently enforced they are bound to be conflicting provisions on a same matter. In this regard, s. 2(2) of OSHA provides that OSHA will prevail over other laws if there are inconsistencies between the former and the latter.

All of the above provisions discussed are about safety and welfare of people, be they employees or visitors. How about safety and welfare of animals kept in the zoos? Conservationists have long highlighted the terrible conditions under which wildlife/animals are kept in zoos (Yoga, 2012). The safety of the animals is at risks if their welfare is not looked after (Hosey et al., 2013; Kleiman et al., 2010). The Malaysian government has taken a positive step in minimizing the problem by gazetting the Wildlife Conservation (Operation of Zoo) Regulations 2012 for Peninsular Malaysia. The Regulations is made possible with the enforcement of the Protection of Wildlife Act 2010 replacing the Protection of Wildlife Act 1972. The new regulation empowers the Department of Wildlife and National Parks (PERHILITAN) to act against errant zoos and wildlife parks. It also addresses issues of wildlife welfare and cruelty to captive animals. 
Table 2. OSHA 1994

\begin{tabular}{|c|c|c|c|}
\hline Provisions & Duties' subjects & Standard of duty & Penalty \\
\hline Sec. 15 & $\begin{array}{l}\text { Employer's general of } \\
\text { duties of safety, health } \\
\text { and welfare towards } \\
\text { employees }\end{array}$ & So far as is practicable & $\begin{array}{l}\text { Fine: }<\text { RM50, } 000 \\
\text { or Imprisonment: }<2 \\
\text { years Or both }\end{array}$ \\
\hline Sec. 16 & $\begin{array}{l}\text { Employer's to formulate } \\
\text { safety and health policy }\end{array}$ & Strict & $\begin{array}{l}\text { Fine: }<\text { RM50, } 000 \text { or } \\
\text { Imprisonment: }<2 \\
\text { years. Or both }\end{array}$ \\
\hline Sec. 17 & $\begin{array}{l}\text { Employer's general } \\
\text { duties towards } \\
\text { non-employees }\end{array}$ & So far as is practicable & $\begin{array}{l}\text { Fine: }<\text { RM50, } 000 \\
\text { or Imprisonment: }<2 \\
\text { years. Or both }\end{array}$ \\
\hline Sec. 18 & $\begin{array}{l}\text { Occupier's duty } \\
\text { towards non-employees }\end{array}$ & As are practicable & $\begin{array}{l}\text { Fine: }<\text { RM50, } 000 \text { or } \\
\text { Imprisonment: }<2 \text { years. } \\
\text { Or both }\end{array}$ \\
\hline Sec. 20 and 21 & $\begin{array}{l}\text { Manufacturer's } \\
\text { duty as regards plants } \\
\text { and substance }\end{array}$ & So far as is practicable & $\begin{array}{l}\text { Fine: }<\text { RM20, } 000 \\
\text { or Imprisonment: }<2 \\
\text { years. Or both }\end{array}$ \\
\hline Sec. 24 & $\begin{array}{l}\text { General duties } \\
\text { of employees at work }\end{array}$ & To take reasonable care & $\begin{array}{l}\text { Fine: }<\mathrm{RM} 1,000 \text { or } \\
\text { Imprisonment: }<3\end{array}$ \\
\hline
\end{tabular}

Table 3. Factories and machinery act 1967

\begin{tabular}{ll}
\hline Part II & Safety, health and welfare \\
\hline Part III & $\begin{array}{l}\text { Persons in charge and certificates } \\
\text { of competency }\end{array}$ \\
Part IV & $\begin{array}{l}\text { Notification of accidents, dangerous } \\
\text { Occurrence and dangerous disease } \\
\text { Notice of occupation of factory, } \\
\text { Part V }\end{array}$ \\
and registration and use of machinery \\
General (including penalties)
\end{tabular}

The new regulation requires zoos to take care of the safety, health and welfare of the captive animals; as follows:

- Adhere to minimum cage sizes according to various animal groups

- Build a quarantine area and a veterinary clinic and hospital

- Employ a full-time consultant veterinarian

- Provide vaccination of animals by a veterinarian

- Provide nutritious and sufficient food for the animals

- Maintain a record of kept animals and their health care

- Ensure the cleanliness of the facility

- Conduct euthanasia of wildlife whenever necessary

- Conduct wildlife shows that involve the animals' natural behaviours only

- Submit a deposit to relevant agency (PERHILITAN) for the upkeep of animals should they be seized

\section{CONCLUSION}

Undoubtedly, legal provisions to ensure safety for both people and animals at zoos are very much required. This is to ensure that the owner and management of zoos place high priority to ensure safety while providing entertainment to the public. In regard to safety of people, the legislation that protects them seems inadequate. This is because the OSHA 1994 which is the principle legislation on occupational safety remarkably might not apply to zoos. The provisions of FMA could arguably be applied to zoos operation. The law of tort can be invoked by an injured party but it requires a personal suit taken against the zoos owner or operator, which is time consuming and costly. For animals' safety, the new Wildlife Conservation (Operation of Zoo) Regulations 2012 is a positive move by the government to ensure safety, health and welfare of captive animals.

\section{ACKNOWLEDGEMENT}

The researchers would like to record his appreciation to Universiti Kebangsaan Malaysia for providing the research grants, Nos. PTS 2012-045 and Industri 2012-005.

\section{REFERENCES}

Conway, W., 1995. Wild and zoo animal interactive management and habitat conservation. Biodiversity Conservation, 4: 573-594. DOI: 10.1007/BF00222515 
Bahari, I., 2002. Pengaturan Sendiri di Dalam Pengurusan Keselamatan dan Kesihatan Pekerjaan. 1st Edn., McGraw Hill, Kuala Lumpur, ISBN-10: 9839340905, pp: 424.

Clerk, J.F. and M.A. Jones, 2012. Clerk and Lindsell on Torts. 20th Edn., Sweet and Maxwell, London, ISBN-10: 0414024540, pp: 272.

Cooke and John, 2007. Law of Torts. 8th Edn., Pearson Longman Harlow.

Derbeken, V.J. and K. Fagan, 2007. Police, fire logs in S.F. tiger mauling show scene of chaos, delay. San Francisco Chronicle.

Fagan, K., V.D. Jaxon, R. Steve and C.M. Vega, 2007. Trail of blood apparently led escaped tiger to victims. San Francisco Chronicle.

Forthman, D.L. and J.J. Ogden, 1992. The role of applied behavior analysis in zoo management: Today and tomorrow. J. Applied Behav. Anal., 25: 647-652. DOI: 10.1901/jaba.1992.25-647

Hassan, K.H., 2001. Undang-undang Keselamatan Industri di Malaysia. 1st Edn., Dewan Bahasa dan Pustaka, Kuala Lumpur, ISBN-10: 983627197X, pp: 164.

Heinrich, H.W., 1959. Industrial Accident Prevention: A Scientific Approach. 4th Edn., McGraw-Hill, New York, pp: 480.

Hosey, G., V. Melfi and S. Pankhurst, 2013. Zoo Animals: Behaviour, Management and Welfare. 1st Edn., Oxford University Press, Oxford, ISBN10: 0199693528, pp: 696.

Jones, M.A., 2003. Textbook on Torts. 8th Edn., Oxford University Press, Oxford, ISBN-10: 0199255334, pp: 784.

Kamal, H.H., 1994. Akta Keselamatan dan Kesihatan Pekerjaan, Satu Huraian. Current Law J.
Kamal, H.H., 2011. Kewajipan majikan di bawah seksyen 15-18 Akta Keselamatan dan Kesihatan Pekerjaan. Malayan Law J.

Kleiman, D.G., K.V. Thompson and C.K. Baer, 2010. Wild Mammals in Captivity: Principles and Techniques for Zoo Management. 2nd Edn., University of Chicago Press, Chicago, ISBN-10: 0226440095, pp: 592.

Laing, A., 2013. Lions kills man at Johannesburg zoo. The Telegraph.

Manning, S., 2013. Helen Schofield, New Zealand Zookeeper, Killed By Mila The Elephant (UPDATED). Huff Post GREEN.

McMahon, B.M.E. and W. Binchy, 2000. Law of Torts. 3rd Edn., Bloomsbury Publishing Plc, ISBN-10: 1845928059, pp: 1295.

Murphy, J. and C. Witting, 2012. Street on Torts. 1st Edn., Oxford University Press, Oxford, ISBN-10: 0199554447, pp: 750.

Rogers, W.V.H., P.H. Winfield and J.J.A. Jolowicz, 2010. Winfield and Jolowicz on Tort. 18th Edn., Sweet and Maxwell, London, ISBN-10: 1847037933, pp: 1225.

Talib, N., 2010. Law of Torts in Malaysia. 3rd Edn., Sweet and Maxwell Asia, Kuala Lumpur, ISBN10: 9675040521 , pp: 503.

Turner, C. and S. Hodge Turner. C, 2004. Unlocking Torts. 1st Edn., Hodder and Stoughton Educational, London, ISBN-10: 0340815671, pp: 448.

Yoga, S.S., 2012. New regulation seeks to improve zoo conditions. The Star Online. 